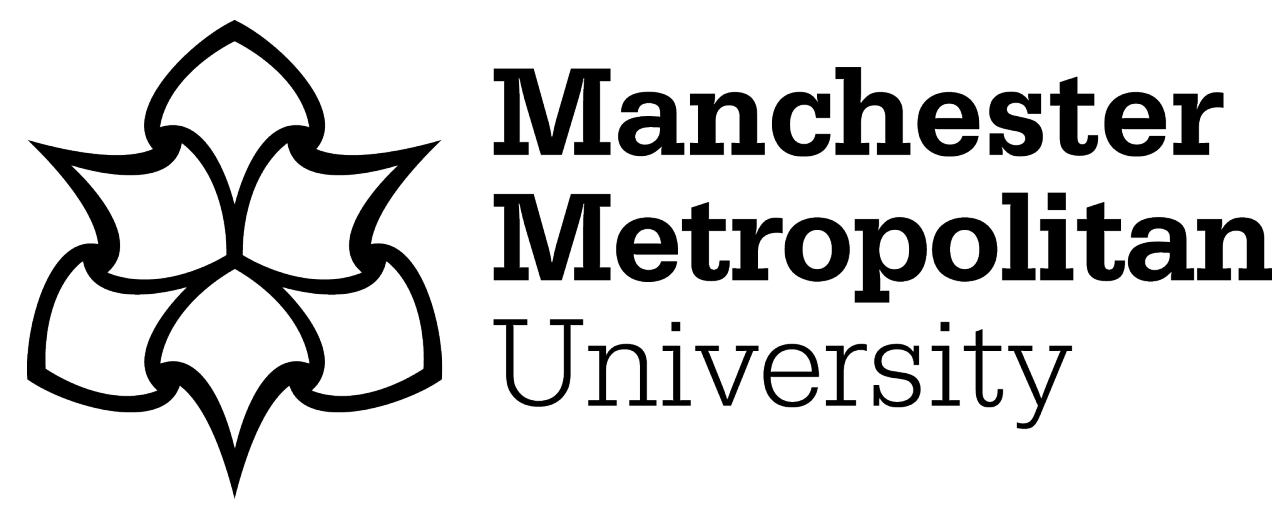

Dendler, L and Dewick, P (2016) Institutionalising the organic labelling scheme in China: a legitimacy perspective. Journal of Cleaner Production, 134 (Part A). pp. 239-250. ISSN 0959-6526

Downloaded from: https://e-space.mmu.ac.uk/621872/

Publisher: Elsevier

DOI: https://doi.org/10.1016/j.jclepro.2016.02.141

Usage rights: Creative Commons: Attribution-Noncommercial-No Derivative Works 4.0

Please cite the published version 
Manuscript Number: JCLEPRO-D-15-01729R3

Title: Institutionalising organic labelling in China: a legitimacy perspective

Article Type: SI: Consumption and Cities

Keywords: Organic Food; China; Product Labelling; Legitimacy; New Institutional Theory

Corresponding Author: Dr. Leonie Dendler,

Corresponding Author's Institution: Sustainable Consumption Institute

First Author: Leonie Dendler, PhD

Order of Authors: Leonie Dendler, PhD; Paul Dewick, PhD

Abstract: Transitioning towards organic consumption and production has been widely promoted as a more sustainable alternative for urban and rural food systems. Our paper shows how a focus on legitimacy can shed light on current barriers to deeper institutionalisation of the organic labelling scheme in China. Based upon documentary analysis, personal observations and over 70 qualitative interviews we identify consequential concerns amongst China's small scale farmers, limited support by the Chinese central government, and procedural problems as the main barriers. We discuss strategies to overcome these barriers, for example tighter certification procedures or more participatory arrangements. Our work contributes to the legitimacy, product labelling and food safety literatures as well as bourgeoning discussions on how to facilitate more sustainable consumption and production in China. 


\title{
Institutionalising the organic labelling scheme in China: a legitimacy perspective
}

\begin{abstract}
Transitioning towards organic consumption and production has been widely promoted as a more sustainable alternative for urban and rural food systems. Our paper shows how a focus on legitimacy can shed light on current barriers to deeper institutionalisation of the organic labelling scheme in China. Based upon documentary analysis, personal observations and over 70 qualitative interviews we identify consequential concerns amongst China's small scale farmers, limited support by the Chinese central government, and procedural problems as the main barriers. We discuss strategies to overcome these barriers, for example tighter certification procedures or more participatory arrangements. Our work contributes to the legitimacy, product labelling and food safety literatures as well as bourgeoning discussions on how to facilitate more sustainable consumption and production in China.
\end{abstract}

Keywords: Organic Food; China; Product Labelling; Legitimacy; New Institutional Theory

\section{Introduction}

Transitioning towards more sustainable agricultural production and consumption in China is increasingly viewed as a crucial piece in the global sustainability puzzle. An alignment with organic labelling standards, in other words, a shift toward organic consumption and production is a widely promoted path to achieve these goals (Vittersø and Tangeland 2015; Reisch et al. 2013; Thøgersen et al. this volume; Yi et al. 2001; Qiao et al. this volume). The stated aim of the International Federation for Organic Agricultural Movement (IFOAM) and the Research Institute of Organic Agriculture (FIBL) is for organic consumption and production to become the mainstream approach to sustainability worldwide (Willer and Lernoud 2015). Some argue (Klintman and Bostroem 2012) that organic trends are already far from being insignificant with obvious potential for overall food transitions. Revenues from sales of organic produce have 
increased almost five fold since 1999 with more and more land certified to organic standards in almost all regions of the world (Willer and Lernoud 2015).

China, home to the world's largest food and beverage retail market (Garnett and Wilkes 2014), has been no exception to this trend. A total organic acreage of 3.529 million hectares (1.287million hectares certified to Chinese organic standards, 0.807 million hectares to foreign organic standards; 1.435 million hectares to wild collection) produced in 2013 a total of 10.808 million tons of organic cereals $(588,000$ hectares), soybeans and other oilseeds $(235,000$ hectares), fruits and nuts $(221,000$ hectares $)$, green fodder $(129,000$ hectares $)$, tea $(53,000$ hectares), vegetables (51,000 hectares), and other plants (22.000 hectares) (Meng et al. 2015), making it the fastest growing sector of Chinese agriculture (Ken Research 2013) and China the fourth largest producer of organic food (Willer and Lernoud 2015).

Early on, the main aim of aligning Chinese agricultural production with international organic labelling standards was to supply Western markets (International Trade Centre (ITC) 2011; Ken Research 2013; Yin et al. 2010). Recent years have seen an increased focus on a rapidly rising Chinese consumer society with organic food officials introducing a national Chinese organic labelling scheme ${ }^{1}$ "to develop retail sales among China's growing urban middle class" (Thiers 2002: 368). The strategy has been partly successful: the domestic market for products certified and labelled through the Chinese organic labelling scheme has grown significantly since the mid-2000s, particularly in first tier cities (ITC 2011; Xie et al. 2011; International Fund for Agricultural Development (IFAD) 2005; Yin et al. 2010; Meng et al. 2015). China is now the third largest organic market in the world in terms of sales (Willer and Lernoud 2015).

\footnotetext{
1 We here define product labeling schemes as comprising three main building blocks coordinated by one or multiple organisational bodies: a standard that provides rules, guidelines or characteristics for product related processes and production methods; an assessment to what extent the specifications of the standard are met; and an aggregation of the assessment results into higher level information communicated on or with the product (Dendler 2013).
} 
Yet despite its strong growth, the organic sector in China is still in its "early infancy" (Thøgersen and Zhou 2012: 316) contributing less than 1\% of China's agricultural production (Meng et al. 2015) and only $0.29-0.44 \%$ of total food consumption (Qiao 2014). By shedding light on current barriers to deeper institutionalisation of the Chinese organic labelling scheme, this paper aims to improve our understanding of how China could contribute more to a global transition towards sustainable consumption and production.

To study these barriers, we focus on the notion of legitimacy as many authors consider legitimacy to be of key importance for organisations (e.g. Meyer and Rowan 1977; DiMaggio and Powell 2008; Dowling and Pfeffer 1975), governance schemes (e.g. Biermann et al. 2010; Borras \& Conzelmann 2007; Knorringa et al. 2011) and sustainability related product labelling schemes (e.g. Cashore 2002; Black 2008; Dendler 2013). So far, research on the Chinese organic labelling scheme has mainly focused on consumer knowledge, understanding and/or willingness to pay as well as barriers at the primary production level. Studies of how the construction of legitimacy may facilitate or hinder alignment with its standards are missing. By addressing this gap, our work contributes not only to bourgeoning discussions on how to facilitate more sustainable consumption and production in China but also the wider product labelling, food safety and legitimacy literatures.

In the following we expand on how previous authors have positioned legitimacy as a crucial variable for the success of social entities. We will then apply these concepts to the Chinese organic labelling scheme showing how legitimacy has been constructed around four main principles: procedures, consequences, disposition and regulation. Our analysis is based on a triangulated approach including documentary review, personal observations and interviews with over 70 stakeholders. We explain our method in section three. We illustrate the usefulness of the concepts by discussing how the construction of legitimacy has shaped alignment with the Chinese organic labelling scheme across different actor groups. We then discuss strategies to facilitate a deeper institutionalisation of the Chinese organic labelling scheme. The last section 
concludes with reflections on our main findings, their implications for the legitimacy literature and further research.

\section{Literature Review}

There is a large interdisciplinary literature on the critical role of legitimacy for the development and success of social entities. Within political sciences, many relate legitimacy to notions of power and authority, framing it as the linchpin that lends justification to the use of power through formal or informal social consent (Beetham 1991). Within organisational studies, legitimacy is seen to determine the support of an organisation across its internal participants and external constituents (Meyer and Rowan 1977; DiMaggio and Powell 2008; Dowling and Pfeffer 1975). Legitimacy is also included in many models of institutional change and institutionalisation processes (DiMaggio 1988; Hargrave and van de Ven 2006; Greenwood et al. 2002). Dendler (2013) emphasizes its importance for the institutionalisation of social entities that aim to provide a new "social order" (Weber 1921), with product labelling schemes being a prominent example of such entities in current societies. This resonates with many other authors who have stressed the importance of legitimacy for product labelling schemes (Cashore 2002; Black 2008) such as the Forest Stewardship Council (Cashore et al. 2006; Waddel and Khagram 2007), the Marine Stewardship Council (Gulbrandsen 2010; Bostroem 2006), the European Union ecolabel (Jordan 2006), energy efficiency (Wiel and McMahon 2005) and organic labels (Hatanaka 2014).

Definitions of legitimacy vary across these literatures. Following a new institutional approach, we define legitimacy as "a generalized perception or assumption that the actions of an entity [in this case the product labelling scheme] are desirable, proper, or appropriate within some socially constructed system of norms, values, beliefs, and definitions" (Suchman 1995: 574). These perceptions are assumed to be based on individual "judgements" (Tost 2011; Bitektine and Haack 2015) along self-interest (i.e "pragmatic"), normative (i.e. "moral") and taken for granted (i.e. "cognitive") dimensions (Suchman 1995). We assume they result in 
behavioural consequences, manifest in non-discursive form, such as engagement in exchange relations or imposition of sanctions or in discursive form as expressions of judgements to other actors through social networks, the media, or other channels (Bitektine 2011; Bitektine and Haack 2015). As such, we hold that legitimacy plays a crucial role in deepening the institutionalisation of product labelling schemes and furthering alignment across systems of consumption and production (Dendler 2013).

New institutional writing emphasizes how (individual) legitimacy judgements are relationally shaped by majority opinion, in particular by "judgement validation institutions" (Bitektine and Haack, 2015) and other "key legitimacy actors" (Dendler 2013) with "superior" (Lawrence and Suddaby, 2006) or "subject positions" (Maguire and Hardy 2009) in the field. For example, positive (individual) legitimacy judgements expressed in newspaper articles can significantly influence other actor's legitimacy judgements and provide crucial information about generalized or "collective-level" (Bitektine and Haack, 2015) legitimacy perceptions. Also, judgements by powerful actors and their respective behavioural consequences can have significant effects on wider (collective level) legitimacy perceptions. Such 'relational pushes' (Dendler and Randles) can include, for example, a powerful corporation expressing its positive legitimacy judgement by aligning its supply chain management with a particular label or a wellpositioned NGO promoting a label in its corporate and consumer communication. From these relational arguments it also follows that organisations can strategically influence the construction of legitimacy for their own organisation (Suchman 1995) and/or a new order they aim to institutionalise (Dendler 2013) through different legitimation strategies.

So far, our picture has been a rather dynamic one painting legitimacy as a social construction between various actors in the field. However, previous studies in the Western context also found stability. Dendler $(2013,2014)$, for example, identified a clustering of legitimacy constructions around several "key principles" (Leca and Naccache 2006), including: 
- Consequences: association with positive or negative consequences in relation to individual self-interests or greater societal welfare (Suchman 1995);

- Procedures: belief in the validity of the procedures followed (Suchman 1995), often related to norms of inclusiveness and deliberation;

- Disposition: belief in the (charismatic) exemplariness of an organisation that is perceived to have "our best interests at heart" (Suchman 1995: 578) and/or holds (traditional) public confidence (Suchman 1995; Weber 1922) (the former is often associated with NGOs, the latter can be attributed, for example, to governmental organisations).

- Regulation: usually evolving from conformity with laws (Tost 2011; Weber 1922; Barker 1990).

With these theoretical arguments in mind, the aim of our research was to investigate the social construction of legitimacy and its impact on institutionalisation in the context of the Chinese organic labelling scheme. To that end we identified legitimation strategies of the organic labelling organisation(s) and generalized legitimacy perceptions and their behavioural consequences in the field. The latter we inferred from judgments aggregated and communicated by "macrolevel judgment validation institutions" (Bitektine and Haack 2015) and from observable behaviour and discourse of other actors, especially "key legitimacy actors" (Dendler 2013). We used a combination of research methods to meet this aim, which are described in section 3.

\section{Empirics}

Firstly, our study drew upon a review of academic and other relevant documents, such as policy reports and plans, administrative documents and organisational reports. All were identified through keyword searches of academic and non-academic databases as well as a review of relevant websites on the Chinese organic labelling scheme. Based upon our review of the legitimacy literature we developed a coding tree consisting of three main branches: 
legitimation strategies applied by labelling organisations; other relational influences through

key actors; wider legitimacy perceptions. We used this coding tree to thematically analyse (Bowen 2009) our material within the software Citavi. Grounded in critical realist thinking (Danermark et al. 2002), we flexibly adjusted our codes as our causal enquiry proceeded.

Secondly, we used primary data from site visits (retail outlets, farmers markets, primary production and manufacturing facilities), personal observations and over 70 in-depth interviews as well as informal conversations conducted between March 2013 and May 2014 (see Appendix 1 for an anonymised list of all interviews). The aim of the interviews was partly to gain insights into individual level legitimacy judgement processes. Mainly however, we aimed to identify generalized or "collective level" (Bitektine and Haack 2015) legitimacy perceptions by interviewing key actors. Key actors were identified during the first phase of the research. By visiting relevant trade fairs (2013 and 2014 Shanghai Biofach; 14th China (Beijing) International Organic Food and Green Food Expo; 15th China (Shanghai) International Organic Food Industry Expo) and by following a snow balling approach we arranged further interviews. Ultimately our study involved interviews with actors from across the Chinese food consumption and production system, including those from primary production, processing, trading, retailing (organic and mainstream) as well as non-governmental, governmental, labelling and certification organisations. Interviews were conducted in both English and Mandarin, the latter with the assistance of a translator. Interview recordings and notes were analysed within the software Nvivo drawing upon and further adjusting the coding tree developed during the first phase of the study.

In the next section we discuss the main organisational bodies involved in organic legitimation strategies at different levels, more precisely in standard setting, certification and communication. In section 5 we present our findings about how legitimacy has been constructed by these labelling organisations, and how it has been perceived and constructed further by other actors in the field. In section 6 we consider how these legitimacy constructions have affected the Chinese organic labelling scheme and discuss strategies to facilitate deeper institutionalisation. 


\section{The Chinese organic labelling scheme}

Similar to other countries in Europe or the United States of America (Steering Committee of the State-of-Knowledge Assessment of Standards and Certification 2012; Stolze and Lampkin 2009), the Chinese organic organisational structure is dominated by the state with respect to standard setting and organisational structure. In 1995, the National Environmental Protection Bureau of China issued the "Organic (Nature) food producing and processing technical specification" and "Organic (Nature) food logo management regulation", which formed the basis for organic labelling in China (Xi 2010). Nine years later, eleven ministries from the central government published the first national policy on organic agricultural promotion (ITC 2011). This was followed in 2005 by the 'Administrative Measures on Organic Product Certification', issued by the Standardization Administration of China and the General Administration on Quality Supervision, Inspection and Quarantine. A major revision of this standard took place in 2014.

The Chinese organic standards partly mimic the principles and requirements of IFOAM Basic Standards for Organic Production and Processing as well as international regulations but with added emphasis on contamination by pollutants and prohibited materials and quality management systems (Marchesini 2009; ITC 2011; Sheng et al. 2009; Xiao and Xiaorong 2003).

Since 1994, the Organic Food Development Centre (OFDC) in Nanjing, which is part of the Ministry for Environment, has been the leading official organisation in charge of inspection, certification and management of organic production in China. Their remit extends to management and supervision of the official organic product logo (Sanders 2006a; Yi et al. 2001 Biao and Xiaorong 2003). According to documents (OFDC-MEP n.d.) and interviews, the OFDC has engaged in planning and research on policies, standard production and technology, as well as publicity, technical support, training and quality control of organic farming. The OFDC are also actively involved in the drafting, revision and evaluation of the organic standards (OFDCMEP n.d.). In 1999, an additional Organic Food Research and Consulting Centre (OFRC) was 
established to further promote "the growth of the organic food industry." The OFRC advises farmers, processors and traders and helps source certified organic fertilizers, pest control materials and physical control materials (OFRC 2006-2014).

Currently the Global Organic Trade Guide (http://www.globalorganictrade.com/countries.php?idx=11) lists 26 national and 6 international certification companies including a certification body within OFDC. As with all certification schemes in China, OFDC needs to be approved by the Certification and Accreditation Administration of the People's Republic of China (CNCA) and accredited by the China National Accreditation Service for Conformity Assessment (OFDC n.d.; ITC 2011). According to their promotional material, OFDC is one of the main professional training facilities for national organic product certification inspectors. OFDC cooperates closely with international organisations such as FIBL, Soil Association, United Nations Environment Programme and the World Bank (OFDC- MEP n.d.) and its certification operation is accredited by the International Organic Accreditation Service under the IFOAM accreditation programme (ITC 2011; Siriex 2011Sanders 2006b).

In summary, one can identify OFDC, OFRC and CNCA as the main organisational bodies involved in legitimation strategies at different levels of the consumption and production system. Certification organisations are also very active in wider legitimacy construction. This includes the building of links between companies; trainings; information services and involvement in the development of organic product standards and policies (see e.g. China Organic Food Certification Centre (COFCC) n.d.). We will now outline how legitimacy has been constructed between these organisations and other actors in the food consumption and production system. 


\section{Constructing legitimacy in the context of the Chinese organic labelling scheme}

We systematically analysed the secondary and primary data according to the theories described above, using legitimacy principles, namely consequences, procedures, disposition and regulation, as the main structure. Where appropriate we further unpacked legitimacy construction across actor groups.

\subsection{Consequential legitimacy}

The organic labelling scheme has been promoted as providing multiple positive societal consequences: "ensuring human health and protecting [the] ecological environment" and contributing to a "healthy sustainable development of the society" in China (OFDC-MEP n.d.). Most dominantly, this has been linked to food safety and potential health benefits on the side of the consumer. This resonates with previous findings on the organic scheme in China (Thiers 2002; Liu et al. 2013; Xie et al. 2015; Klein 2011) and in other countries (Stolze and Lampkin 2009; Klintman and Bostroem 2012; Steering Committee 2012; Thogersen et al. 2015a).

Across actor groups, analysis of the interview and documentary evidence reveals that both promotion and support based on environmental benefits (e.g. reduction of water and soil pollution, protection of biodiversity), animal welfare, and equality goals (e.g. rural development and greater protection of and welfare for farmers and their spouses) have limited impact. For example, one interviewee asserted: "Consumers are worried about food safety. The companies cultivated demand for organic based on that mind set. [...] the organic industry is kind of twisted: organic is actually about harmony between people and nature and not about food safety." (Interview 24, translated). The following sub-sections will discuss in more detail how different consequential self-interests shaped judgements across actors groups, including primary producers (farmers), manufacturers, retailers and consumers. 


\subsubsection{Primary producers}

Economic and market related benefits are commonly mentioned in interviews and documents (Oelofse et al. 2010, 2011; IFAD 2005; Zhang et al. 2015) as positive consequences of an alignment of primary production with organic standards. These benefits include creating recognition with and meeting demands of consumers, higher market prices, differentiation from competitors and better market access through improved positioning with retailers and manufacturers. However, not all interviewees recognised these benefits with several commenting on insufficient demand and limited opportunities for price premiums. Farmers often refer to additional labour and knowledge requirements as well as higher financial and time costs (see also IFAD 2005; Oelofse et al. 2010; Qiao 2010; Cadilhon 2009; Xi 2010; Kuehl and Yonggong 2014; Xio and Xiaorong 2003; Liu et al. 2010; Zhang et al. 2015; Sanders 2006a; Sanders 2006b). Interviewees repeatedly communicated problems of getting access to modern organic technology, including organic pesticides and fertilizers, but also access to suitable land. One interviewee commented how the "price of land is increasing but even if you have enough money you can still not get enough land....because they have to find agreement with all the farmers as in China the land belongs to everybody" (interview 37, translated).

In addition, farmers spoke of long conversion periods during which they were likely to see yield decreases (see also Xiao and Xiaorong 2003; Zhang et al. 2015; Sanders 2006b). One interviewee for example described: "Crop yield is lower especially for small and new companies as the organic fertilizer is effective only very slowly. If the fertility [of the soil] is not high, the yield will go down. And the crop disease will be higher" (interview 37, translated).

Whilst IFAD (2005) advocates a stronger consequential orientation towards wider benefits, such as drought resistance and erosion reduction, improved local nutrition security or protection of biodiversity and clean water sources, we found that such benefits were mentioned less frequently as consequential motivations (Oelofse et al. 2010; Cadilhon 2009; Yin et al. 2010; Liu et al. 2013). Instead, pragmatic support mechanisms, in particular from local government organisations, appear to be more effective. These include technical and financial (e.g. lower tax 
rates, direct payments, investment and loan privileges, subsidized rental rates and land donations, subsidized bio-pesticides, seeds or organic fertilizers and initial financing for certification), organisational, marketing and market access support (see also IFAD 2005; Sanders 2006a; Taylor 2008; Thiers 2002, 2005; Qiao 2010).

\subsubsection{Manufacturers and retailers}

During interviews, primary producers often mentioned demand from manufacturers and/or retailers as incentives for the support of the organic scheme. Manufacturers pointed to consumer demand and brand image as potential consequential benefits but mainly talked about the associated costs for human resources, certification, materials and processing technology. As organic certification usually needs to be obtained for every ingredient, negative consequences can emerge from having to manage, control and certify often highly fragmented supply chains.

For retailers, consumer demand and potential price premiums are prominent gains, both in documentary (e.g. Ken Research 2013) and interview data. Similar to Western markets (Dendler 2013) consumer surveys are influential. One interviewee from the retail realm (interview 66) describes for example how retail managers are driven by a desire to meet consumer demand in reaction to consumer surveys that communicate higher willingness to pay for organic certified products. Increased food safety concerns, provoked by media coverage of various food safety scandals as well as activities by non-governmental organisations (NGOs) have created interest from retailers in providing traceable products (see also Scott and Suarez 2012). For example, Greenpeace exposed major supermarket chains selling products with illegal pesticides and made the connection with negative impacts on human health (Greenpeace 2006a, 2006b). Over the next few years Greenpeace continued to put pressure on retailers to ensure their supply chains were transparent and to minimise pesticide residues (Greenpeace 2011a, 2011b, 2012). While NGOs generally play a comparatively small role in the Chinese organic labelling scheme (see further discussion in section 5.2.3), such activities have captured much attention, especially within Chinese social media. As such, it resonates strongly with NGO driven "individualised collective action" (Clarke et al. 2007) and "naming and shaming" (Steering 
Committee 2012) dynamics prominent in Western labelling contexts (Steering Committee 2012; Gulbrandsen 2006).

\section{$\underline{5.1 .3 \text { Consumers }}$}

Both documents (Yin et al. 2010; Lin, et al. 2010; Liu et al. 2013; Cadilhon 2009; Wang 2014a; Xi 2010; Xie et al. 2015; Yip and Janssen 2015; Siriex et al. 2011) and interviews frequently blame high prices for negatively affecting consequential perceptions on the consumer side. Higher production costs, as well as premiums added along the supply chain, means the price of most organic products is at least two to five times higher than that of conventional products (Meng et al. 2015; Thogersen et al. 2015a). To overcome this barrier, many previous studies (e.g. IFAD 2005; ITC 2011; Yin et al. 2010; Cadilhon 2009; Taylor 2008; Liu et al. 2013; Veeck and Burns 2005; Wang 2014a; Willer and Lernoud 2015: Xie et al. 2015; Chen et al. 2013; Yip and Janssen 2015; Siriex et al. 2011) and nearly all interviewees pointed to the relevance of perceived food safety and health benefits, especially for children. Food safety has become one of the most prominently discussed societal issues in China, including controversies around excessive pesticide and other chemical use and, to a lesser degree, potential negative health impacts associated with genetically modified organisms (Liu et al. 2013; Zhang et al. 2012; Wang et al. 2008; Wu et al. 2011; Whitehead 2015; Xu et al. 2012; Yin et al. 2010; Yang 2011; ITC 2011; Klein 2011). The purchase of organic certified products has been communicated as directly addressing such concerns by providing a healthier and safe alternative that is more "fresh" (interviews 14/23), "tasty" (interviews 5/20/64), "nutritious" (interviews 19/20) and free of genetically modified substances, pesticides, fertilizers and carcinogens (see also Cadilhon 2009). OFRCC, for example, promotes the "virtues of organic food: healthy, security and tasty" (Xi 2010). Another interviewee from a certification company described how they organize events for new born babies, young children and the elderly in health centres and hospitals during which nutritionists emphasize the health benefits associated with the consumption of organic certified products (Interview 8). Our own observations supported such descriptions. Resonating with Klein (2011) we found connections to traditional food therapies that draw upon a close 
relationship between human health, nature and rural livelihoods. Recent restructuring strategies target this issue more explicitly by shifting the organic standard from non-use of prohibited materials to one of non-contamination and residue free production assurance (Lernoud et al. 2013). We discuss these and other procedural changes in the next section.

\subsection{Procedural legitimacy}

Many interviewees referred to the organic scheme as helping to create "recognition" (e.g. interview 53) and "trust" (e.g. interview 26). However, both the previous literature (Ken Research 2013; Liu et al. 2013; Scott et al. 2014; Taylor 2008; Veeck et al. 2010; Xie et al. 2015; Chen and Lobo 2012) and our interviews also point to significant procedural criticism. Some interviewees related this to a "general trust crisis" (interviews 23) and a "lack of credibility for certification" (interview 68) created by "shadows left" (interviews 41) from previous food scandals; others made explicit links to procedural shortcomings of the organic labelling scheme itself.

Calls for multi stakeholder participation, inclusiveness and transparency, considered highly important in Western contexts (see e.g. Gulbrandsen 2010; Boström and Klintman 2008; Meidinger 2008), were not prominent in our research. While the CNCA has enabled participation in standard setting by posting standards online for public feedback or inviting academics, certification companies and other organisations to comment, interviewees emphasized limited engagement. One interviewee explained: "I think the Chinese public does not have the awareness to be involved and give comments.... I know when USDA [United States Department of Agriculture] issued the draft they had more than 10000 comments from producers and all stakeholders. But for our standard, not so much: less than 1000 maybe [and] the main comments came from the certifier" (interview 4).

At the same time we find concern about dominant state actors and potential conflicts of interests with the certification process (Thiers 2002; Kuehl and Yonggong 2014; Organic Trade Association; Wei 2012). In 2011 Chinese national television reported how certification "could 
easily be bought" as some certification departments, producers and retailers were "willing to stick organic food labels onto non-organic food in order to make more money. [...] Organic food such as vegetables from producers that claim not to use chemical fertilizers or pesticides cannot be entirely trusted" (Zhang 2011). Wal-Mart, amongst others, was accused of fraudulently selling organic products (Wang 2011); an online newspaper reported that "organic certification officials regularly accept 'gifts' from food companies in China" (Wei 2012). Similar criticism featured frequently in our interviews describing how certification companies are in fierce competition with each other and would interpret the organic standards with different degrees of stringency. Others reported how some companies would sell all their products as organic even though only some of them received certification.

Such prominent procedural criticism has had serious effects not only on consumer but also corporate legitimacy judgements (Ken Research 2013; Yin et al. 2010; Liu et al. 2013; Scott et al. 2014; Taylor 2008; Veeck et al. 2010; Xie et al. 2015). One interviewee from a main retail chain for example argued: "...it is difficult for retailers to be 100 percent sure that the products are organic .....the consumer will have a question mark when they go to [retailers] as there has been a lot of negative news in the past. Products were labelled organic but were actually not" (interview 68).

CNCA officials have publicly acknowledged exaggeration and false promotion, nonstandardised use of the label and insufficient control of the circulation of the label. In response, CNCA engaged in multiple procedural repair strategies. Interviewees reported how immediately following the national TV coverage, CNCA asked all certification organisations to recheck their documentation, resulting in the withdrawal of many certificates. Shortly after, the National Standards for Organic Products were revised, according to Scott et al. (2014: 161) to better "protect against fraud". Major changes included not only zero-tolerance for residues but also the introduction of authentication codes for each product to enable consumers to trace their origin (the barcode scheme); prohibition of parallel planting in one-year crops; certified inspection of each crop variety; and inspection of all farms in cooperative groups (Hallmann and Xu 2012). 
CNCA announced that they would also increase the control over certification organisations; increase risk management; and strengthen risk assessment of employees through the certification companies. Associated with these changes, a number of interviewees commented on stricter standards, increased monitoring and better traceability; how it was "easy to bribe certifiers in the past but not anymore. [...] They come and test every piece of land" (interview 41).

But despite procedural progress, both interviews and documents suggest that procedural problems are not fully solved. During the 2014 Shanghai Biofach Fair, the director of CNCA reported ad hoc checks were still finding around 15\% of products using the term organic even though they are incorrectly or not at all certified, around 2\% exceeding pesticide levels and 3\% not being fully in line with other organic regulation (Wang 2014a).

\subsection{Dispositional and regulatory legitimacy}

Our research found some NGOs, such as the World Wildlife Fund, and other civil societal organisations (Klein 2009; Nanjing Global Organic Food Research and Consulting Center 20062014; OFDC-MEP n.d.; Monica Tan 2012) actively promoting the organic scheme. In line with dominant consequential concerns, this promotion is linked mainly to health and food safety through events in health clubs or schools (see also Klein 2011). To some extent this contributes to what may be referred to as 'dispositional legitimacy' in the form of a belief in organisations that are perceived to operate in our best interests. But overall, NGOs play a comparatively small role in the Chinese organic scheme, a finding that resonates with previous studies (Oberheitman 2009; Sun and Zhao 2007; Geall and Hilton 2014).

Instead, the role of the state occupies the foreground. Next to the pragmatic support described above, interviewees described how governmental involvement in the organic labelling organisation contributes to the creation of trust: "without government nothing can happen" (interview 10), "government has to stand behind" (interview 13) as it is "important" (interview 40) and "most powerful" (interview 21). Such statements resonate with consumer surveys in the food context (Ortega et al. 2011; Liu et al. 2013) and other academic studies on China (e.g. Wang 
2005 or Zhang et al. this volume) who refer to high levels of trust in the central government in a more abstract sense (as opposed to activities carried out at the local level). It seems that governmental involvement in product labelling facilitates cognitive acceptance based on what Weber referred to as "immemorial traditions that have always prevailed and the legitimacy of those exercising authority under them" (Weber 1922: part 1, III, 1, 2). Further supporting such arguments, we find a number of authoritative governmental interventions. These include the conversion of land for the establishment of ecological agriculture zones or the initiation of individual farm conversions (Scott et al. 2014; OFDC-MEP n.d.; IFAD 2005; ITC 2011; Thiers 2002, 2005; Qiao 2010; Xi 2010; Sanders 2006b). Thiers (2002: 396) speaks of "administrative methods to convince the peasants" to engage in organic farming, which implies that "if a peasant family refuses to participate, they are moved off the land and exchanged with a family from another field who are willing to cooperate". IFAD (2005) notes that with increasing trends towards market orientation local governments are moving away from direct ownership and have transferred rights to private firms. However, this process has allegedly left some of the former public companies in the private hands of local government leaders, which often enjoy unique advantages and support for their contracted farmers. In many communities former state owned farms and collectives continue to exist and often direct rural industry and sideline production (Selden and Perry 2010; Sanders 2006a). More recent management literature reemphasises how especially in sectors based on key resources, such as land, China maintains strong ties between government and business (Walder 2011, Shi et al. 2014). Our interviews supported such propositions, reporting governmental initiation of organic conversion, encouragement to engage in organic promotion and the relevance of organic alignment in governmental evaluation of local companies.

The Chinese central government is also involved in what can be referred to as regulatory legitimation as all products using the term "organic" or other characters, graphics or symbols suggesting organic production need to comply legally with the national organic regulation (National Standard of the People's Republic of China). While this regulation used to be mainly 
enforced with respect to the Chinese language, law enforcement has recently started to extend its scope to the use of the term in other languages (Hallmann and Xu 2012).

\section{Discussion}

In the following we discuss how legitimacy constructions outlined in the previous sections have affected support for the Chinese organic labelling scheme within the current production and consumption system. We then reflect on strategies organic labelling organisations may apply to achieve more positive judgements and facilitate deeper institutionalisation.

\subsection{Primary producers}

As a result of the rural reforms of the early 1980s (Sanders 2006; Selden 2010; Zhang et al. 2013), farming in China is conducted by millions of small farmers with an average farm size of 0.6 hectares often living on an income of less than $\$ 2$ per day (Carter et al. 2002; Garnett and Wilkes 2014). While some argue that "farmers' poverty has been one of the primary factors in predisposing them to take the risks involved in converting to organic methods" (Sanders 2006a: 127), our research finds significant consequential barriers. These relate partly to capacity problems in terms of finance, quality control, harvesting or post-harvest techniques. Few farmers in China have the ability to operate and negotiate within a complex value chain (IFAD 2005; Hu et al. 2008; Jia et al. 2012). Price premiums, usually gained in urban areas and/or by other market actors, or long term contracts with buyers are not easily available (Yang 2011/2012; Thiers 2005). Increasing pollution levels and competing demands from the construction and other sectors amplify longstanding land access challenges while current ownership structures reduce incentives for investment into the land (Wang 2014b; Li Chenggang 2013).

Capacity problems for smallholders are not an issue limited to China. It is a widely recognized problem within the organic movement (Willer and Lernoud 2015; Klintman and 
Bostroem, 2012) and with many other sustainability labelling schemes (Matus Forthcoming; Dendler 2013; Steering Committee 2012). However, the very high number of small scale farms in China makes this a more acute challenge.

\subsection{Governmental actors}

IFAD (2005: 5) conclude that the most important factor for successful organic adoption in China is the availability of a reliable support system, an assertion supported by interviewees for this study. Echoing other studies in the Chinese food context (e.g. Zhang et al., this volume; Mol 2014), our research finds a particularly strong role for governmental actors, not only in pragmatic and more abstract trust building terms, but also in more authoritative terms where they can draw upon their traditional position in the Chinese agricultural system. In this sense our findings resonate with previous authors who refer to China as "fragmented authoritarianism" (Geall and Hilton 2014) or a "fragmented entrepreneurial state" (Thiers 2002: 358) where state actors use political authority through "an unassailable civil service" (Fan et al. 2011: 18) as well as competitors in the socialist market economy (Thiers 2002).

However, it is interesting to note the limited extent to which government has exercised these types of power. While developing organic agricultural products has appeared repeatedly in China's central policy documents (Liu et al. 2013), been promoted by some of its senior party leaders (Sanders 2006a) and incorporated into local government promotion schemes to facilitate green development and "eco-civilization" (Meng et al. 2015; Wang 2014a; Qiao 2010; Xi 2010), our research suggests more scope for governmental influence. Many interviews, documents (e.g. IFAD 2005) and academic studies (e.g. Zhang et al. 2013) argue that central government support has been comparatively low, lacking "substantial funding" (Qiao 2010) and falling behind the support of other product labelling schemes such as the Green Food Label².

\footnotetext{
2 Next to the organic labelling scheme, the Chinese Ministry of Agriculture hosts a so called Hazard Free and a Green Food labelling schemes. While the emphasis of Hazard Free food is on the residue content, Green Food is based on concepts of environmental protection and sustainable development. Unlike the organic scheme both allow for
} 
Indeed, the vast majority of resources still promote conventional agriculture (IFAD 2005). Some observers point to competing ministerial priorities (Taylor 2008), especially in regard to food security. Given lower productivity rates and greater demands by organic agricultural practices on highly scarce land resources, it is widely considered that organic production cannot provide for China's growing population (Xie 2008; Chen \& Wan, 2005; Xiao this issue; Scott et al. 2014; Zhang et al. 2013). As one interviewee from a governmental organisation involved in the organic labelling scheme points out: "China is a very big country with a big population so the highest priority is to produce enough food for the population, and then it is [about] producing safe food and then it is [about] the environment. That is why the aims for organic are limited" (interview 7).

\subsection{Manufacturers and retailers}

In light of limited governmental support, market actors seem to have become more relevant for the institutionalisation of the Chinese organic labelling scheme. In the Western context, major retailers and branded manufacturers have exercised significant influence on the institutionalisation of organic and other sustainability related product labelling schemes (Dendler 2013; Steering Committee 2012; Bostroem and Klintmann 2008; Gulbrandsen 2006; Klintman and Bostroem 2012). Several interviewees saw large agricultural companies also as major drivers of the Chinese organic scheme. Generally however, organic food processing is presently in a nascent stage with retailers complaining about insufficient availability of organic (processed) products and the majority of organic farm products being sold as raw products (IFAD 2005; Ken Research 2013; Meng, Fangqiao et al. 2015). Our research suggests the main barriers for wider manufacturing support are: restricted scope of organic standards (i.e. criteria only covering some processing); difficulties in certifying multi staged, often highly fragmented Chinese food supply chains; procedural contestations and limited 'relational push'.

\footnotetext{
controlled and limited use of synthesized fertilizer, pesticide, growth regulators, feed additives and gene technology (Liu et al. 2013). They are hence sometimes considered as "half-way house" between conventional and organic food (Paull 2008).
} 
Similar barriers hinder retailers. While some documents suggest that conventional supermarkets have become the main channel for selling organic produce (ITC 2011; Xie et al. 2011; Taylor 2008; Meng et al. 2015; Yip and Janssen 2015; Siriex et al. 2011), we found negative perceptions and very reserved support for (and further relational influence on) the organic labelling scheme among mainstream retailers.

\subsection{Consumers}

The limited relational push from manufacturer and retailer side can partly be explained with dominant perceptions of consumer demand. While consumer studies identify some demand and willingness to pay for organic certified products amongst Chinese consumers (ITC 2011; Liu et al. 2013; Xie et al. 2011; Yin et al. 2010; Zhang et al. this volume; Yip and Janssen 2015), this demand is generally considered to be limited to high income consumers in major cities (Lin et al. 2010; Thøgersen and Zhou 2012; Yin et al. 2010; Xie at al. 2015; Thøgersen et al. 2015a; Siriex et al. 2011). Multiple sources of interview, academic and documentary evidence report collective consumer knowledge and awareness of the organic label to be low, with considerable confusion between different schemes (Yin et al. 2010; Zhang et al. 2012; Liu et al. 2013; Xi 2010; Zhang et al., this volume; Xie et al. 2015; Wu et al. 2014; Chen and Lobo 2012; Yi et al. 2001). With current media reporting on the organic scheme focusing mainly on procedural inconsistencies, we find rising mistrust among Chinese consumers and businesses alike. Linked to these procedural doubts, public criticism raises questions about the consequential benefits associated with the purchase of domestic organic certified products and facilitates a shift towards imported rather than Chinese organic certified food (Xie et al. 2011; Walley et al. 2014; ITC 2011; Yip and Janssen 2015; Wu et al. 2014).

\subsection{Potential strategies to facilitate deeper institutionalisation}

In the light of such developments, improving perceptions of procedural legitimacy has become one of the main challenges for the deeper institutionalisation of the Chinese organic labelling scheme. This resonates with global organic trends, where there are increasing problems with fraud (Gould 2015), and wider discussions about inconsistencies in standard 
interpretations (e.g. Steering Committee 2012 on sustainability labelling in general; Jacquet et al. 2010 on the Marine Stewardship Council or Allison et al. 2000 on ecolabelling schemes) as well as general conflicts of interest in paid certification processes (e.g. Matus forthcoming). For the Steering Committee of the State-of-Knowledge Assessment of Standards and Certification (2012: 15) 'auditor competence' is "one of the most significant challenges to the integrity and credibility of voluntary standards and certification".

To overcome these challenges, some interviewees called for deeper institutionalisation of social norms like honesty and trustworthiness. Others demanded a reduction of the number of certification companies involved, more severe punishments or more regular checking processes (see also Chen and Lobo 2012). But with increased procedural demands usually comes greater costs for those in supply chains which, as outlined above, can hinder consequential motivations of especially small scale producers. ${ }^{3}$ Again we find overlaps with international certification and labelling discussions around appropriate levels of standards stringency (e.g. Boström and Klintman 2008 on general sustainability labelling dynamics; Erkine and Collins 1997 on the EU ecolabel; Steinruecken and Jaenichen 2007 on the Fairtrade scheme).

Bottom-up initiatives are an alternative way forward that does not rely on certification. Although there is no formal support in the Chinese organic regulations for 'Participatory Guarantee Schemes' and participants are not allowed to use the term organic (Wai 2015), our research found evidence of many primary producers engaging directly with consumers through membership schemes, farm visits, farm shops and home deliveries. Many of these new initiatives echo descriptions by other authors (Zhang et el. this volume; Si et al. 2014; Scott et al. 2014; Qiao 2014) of emerging "alternative food networks" (Zhang et al., this volume), in particular

\footnotetext{
${ }^{3}$ For example, recent procedural adjustments are already said to facilitate a shift away from small scale farming (which tends to include a variety of crops and is hence associated with more bureaucratic steps) towards large scale mono cultures. Such trends further contribute to what some see as an increased "conventionalisation" (Oelefse et al. 2011) of the organic scheme as well as growing urban migration.
} 
'Community Supported Agriculture' or 'Participatory Guarantee Systems' (Kirchner 2015) schemes.

Within such schemes certification plays a less important role. Interviewees reported how they wanted to "sell to consumers who have built trust in their brand without certificate" [interviewee 39, translated] and to have "proper relationships" with customers and "build a community" (informal conversation 75). Similar findings are described by Scott et al. (2014). Some actors within the global organic movement argue that "the world needs to escape the limited perception that organic equates with certification" (Gould 2015: 138). David Gould (2015: 138) from IFOAM, for example, calls for "a new market assurance framework" that moves towards a focus on common interest and transparency with more participation. Rather than formal third-party certification, 'Community Supported Agriculture' and 'Participatory Guarantee Schemes' are based on "active participation" of closely linked groups of producers, technology consultants and consumers "built on a foundation of trust, social networks, and knowledge exchange" (Nanjing Global Organic Food Research and Consulting Center 20062014). Resonating with previous findings in the Chinese food sector (e.g. Zhang et al. this volume; Zhang et al. 2008; Veeck et al. 2010), several of our interviewees supported the importance of trust building through "seeing" (e.g. interviews 10/36/37/39/51/58), "trying" (e.g. interview 10) and "tasting" (e.g. interviews 43/53/58) and relational dynamics where "old customers will promote [their products] to new customers" (interview 43). As such, these schemes fit well with a Chinese traditional focus on personal experience (e.g. extensive individual checking prior to food purchase) and direct relational links (Berkenama et al. 2015; Redding and Witt 2006; Veeck et al. 2010; Hoiman and King 2008) in what some authors refer to as a "lowtrust society" (Sheng et al. 2009). They also fit into central governmental rhetoric of a shift towards "social-co-regulation" (Xiao 2015) to ensure food safety or environmental protection (Horsley 2006; Geall and Hilton 2014).

Indeed, Scott et al. (2014) propose that consumers and small producers increasingly “reject the state's assurances and begin the complex civil process of reconnecting and re- 
negotiating trust through direct relationships between producers and eaters" (Scott et al. 2014:164). Zhang et al. (this volume) on the other hand report comparatively low uptake of 'Alternative Food Networks' even among wealthier and higher educated Chinese consumers and suggest a continuous high trust in central government. Our research supports especially Zhang et al.'s (this volume) latter point and additionally highlights less prominence of norms of participation and inclusiveness in the Chinese context. While this resonates with previous scholars that emphasize the importance of Confucian values of authority, obedience and harmony rather than individual expression in China (e.g. Gamer 2008; Christiansen and Rai 1996), it is in considerable contrast with findings in the West as well as some the core idea of 'Alternative Food Networks'.

Calls to "focus on [the] common interest" (Gould 2015) also begs questions about what this implies. Across our interviews and consistent with previous studies within and beyond China's 'Alternative Food Networks' (Si et al. 2014; Scott et al. 2014; Wang et al. 2014; Klein 2011) we found a dominant consequential focus on monetary, health and other individual interests with limited orientation towards societal benefits of rural development, environmental protection or other "collective" aims (Barkema et al. 2015; Tang 2009). This may change as China moves from a focus on subsistence and safety towards other 'Chinese dreams'. Yet, so far, the exact content of those dreams and the extent to which they resonate with principles of sustainable development remains to be seen. Vitterso et al. (2015) conclude in their recent study on organic consumption in Norway that it is important to open up the debate on what constitutes sustainable food consumption and production. We would add to this that it is crucial to take into account different contextualities within this debate.

\section{Conclusion}

Considering the rising economic, social and environmental importance of Chinese consumption and production systems, a better understanding of institutional changes within these systems is needed. Our paper focused on a transition towards organic consumption and 
production. By shifting attention to the notion of legitimacy, we identified barriers for such a transition and explored the role of different actors and currently considered strategic adjustments in overcoming those barriers.

We find that in the highly fragmented Chinese agricultural system, perceptions of negative consequences associated with the support of the organic scheme are dominant. This holds for retailers and manufacturers but especially primary producers, who must make considerable adaptations to their practices to align with organic standards. Positive relational impacts are promised from the consumption stage but there is currently insufficient evidence of a translation of health and food safety concerns into consumer demand for organic produce. This partly relates to procedural legitimacy challenges associated with a dominant discourse around corrupt certification. These problems have given rise to calls for a tightening of organic labelling procedures. Yet the unintended effect of such strategies is additional requirements for producers, which negatively affect consequential evaluations for small scale producers and, some argue, for society as a whole. As such, an inherent conflict between procedural and consequential aspects emerges, which mirrors findings in other sustainability product labelling contexts.

Reconfiguration of the Chinese organic labelling scheme towards more bottom-up participatory arrangements offers an alternative way forward. At least for the moment however, 'Alternative Food Networks' are very much inspired by Western values of participation, which seem to find limited support in traditional Chinese culture.

In these circumstances, construction of legitimacy around other principles, in particular disposition and regulation, become more relevant. Our analysis highlights an important role for government, which can exercise its influence through regulation and its 'taken for granted' authoritative position in the field. But for the organic case, this role is not clear cut as government must balance the promotion of the organic scheme next to other priorities, 
including other product labelling schemes, and conflicting objectives within (e.g. food security) and beyond (e.g. support for industrial and construction sectors) agriculture.

Our study illustrates the value of applying concepts of legitimacy to better understand current barriers to deeper institutionalisation of the Chinese organic labelling scheme. Many of the legitimacy principles identified in Western contexts have been shown to be relevant also in the context of the Chinese organic labelling scheme, supporting their ontological positioning on a "real" level (Leca and Naccache 2006). However, significant differences emerge with regard to their interpretation. In particular, procedural norms of deliberation and inclusiveness are much less prominent. Dispositional dynamics, in the Chinese context mainly associated with a strong traditional belief in the authority of central government rather than the exemplariness of NGOs, are of greater importance. Further research should establish to what extent these findings could help to understand better also other institutional processes in China.

\section{Acknowledgements}

The authors gratefully acknowledge the Sustainable Consumption Institute and the Fudan Tyndall Centre for Climate Change Research in their financial support for this research. We would furthermore like to thank Yusi Lin and Azura Gao for their interpretation assistance, Nicola Hutson and $\mathrm{Ni} \mathrm{Ye}$ for research assistance and all interview participants for taking the time to share their insights.

\section{References}

Allison, C.; Carter, A. 2000: Study on different types of Environmental Labelling (ISO Type II and III Labels). Proposal for an Environmental Labelling Strategy. Edited by European Commission, DG Environment. Oxford.

Bai, J.; Zhang, C. and Jiang, J. 2013. The role of certificate issuer on consumers' willingness-to-pay for milk traceability in China. Agricultural Economics 44(4-5), 537-544.

Barkema, H. G., Chen, X.-P., George, G., Luo, Y., and Tsui, A. S. 2015. West Meets East: New Concepts and Theories. Academy of Management Journal, 58(2), 460-479.

Barker, R., 1990. Political Legitimacy and the State. Clarendon Pr, Oxford.

Biao, X., and Xiaorong, W. 2003. Organic agriculture in China. Outlook on Agriculture 32(3), 161164. 
Biermann, F.; Betsill, M.; Gupta, J.; Kanie, N.; Lebel, L.; Liverman, D. et al. (2010): Earth system governance. a research framework. International Environmental Agreements: Politics, Law and Economics 10, pp. 277-298.

Bitektine, A. 2011. Toward a Theory of Social Judgments of Organizations: The Case of Legitimacy, Reputation, and Status. Academy of Management Review, 36(1), 151179.Bitektine, A. 2011. Toward a Theory of Social Judgments of Organizations: The Case of Legitimacy, Reputation, and Status. Academy of Management Review, 36(1), 151-179.

Bitektine, A. and Haack, P. 2015. The "Macro" and the "Micro" of Legitimacy: Toward a Multilevel Theory of the Legitimacy Process. Academy of Management Review 40(1), 49-75.

Black, J. 2008. Constructing and contesting legitimacy and accountability in polycentric regulatory regimes. Regulation and Governance 2(2), 137-164.

Borras, S.; Conzelmann, T. (2007): Democracy, Legitimacy and Soft Modes of Governance in the EU: The Empirical Turn. Journal of European Integration 29 (5), 531-548.

Boström, M. 2006. Establishing credibility: Practising standard-setting ideals in a Swedish seafood-labelling case. Journal of Environmental Policy and Planning 8(2), 135-158.

Boström, M. and Klintman, M. 2008. Eco-standards, product labelling and green consumerism. 1. publ. Basingstoke: Palgrave Macmillan.

Bowen, G. (2009): Document Analysis as a Qualitative Research Method. In: Qualitative Research Journal 9 (2), S. 27-40.

Brunsson, N. and Jacobsson, B. 2000. Following Standards, in Brunsson, Nils and Jacobsson, Bengt (Ed.): A World of Standards. Oxford, New York: Open University Press, 127-137.

Cadilhon, J. 2009. The market for organic products in Asia-Pacific. China BioFach, Shanghai, China.

http://www.fao.org/docs/eims/upload/261001/Cadilhon\%202009\%20China\%20BioFach \%20presentation.pdf [Checked 2014-04-23].

Calvin, L., et al. 2006. Food Safety Improvements Underway in China: ECONOMIC RESEARCH SERVICE/USDA. 4.ed.

Carter, Colin A., Zhong, Funing and Zhu, Jing 2012. Advances in Chinese Agriculture and its Global Implications. Applied Economic Perspectives and Policy 34(1), 1-36.

Cashore, B. 2002. Legitimacy and the privatization of environmental governance: How non-state market-driven governance systems gain rule-making authority. Governance 15(4), 503-529.

Cashore, B., Auld, G. and Newsom, D. 2006. Legitimizing Political Consumerism: The Case of Forest Certification on North America and Europe, in Micheletti, Michele (Hg.): Politics, products, and markets: Exploring political consumerism past and present. New Brunswick: Transaction Publ., 181-199.

Chen, F., and Wan, K. (2005). Letter to the editor: The Impact of organic agriculture on food quantity, food quality and the environment: a China perspective. Soil Use and Management, 21, 73-74.

Chen, Y. et al. 2013. Accumulation and health risk of heavy metals in vegetables from harmless and organic vegetable production systems of China. Ecotoxicology and Environmental Safety 98, 324-330.

Chen, J., and Lobo, A. 2012. Organic food products in China: determinants of consumers' purchase intentions. The International Review of Retail, 22(3), 293-314.

Christiansen, F., and Rai, S. 1996. Chinese Politics and Society: An introduction. Herfortshire: Prentice Hall Europe.

Clarke, N.; Barnett, C.; Cloke, P.; Malpass, A. 2007: Globalising the consumer: Doing politics in an ethical register. In Political Geography 26 (3), 231-249.

COFCC n.d. China Organic Food Certification Centre: Promotional Flyer. Beijing. http://www.ofcc.org.cn/ [Checked May 2013].

Danermark, B., Ekström, M., Jakobsen, L. and Karlsson, J. (2002) Explaining society: Critical realism in the social sciences. Routledge, London. 
Dendler, L. 2013. Sustainability Meta Labelling: Prospects and potential challenges for institutionalisation. PhD Thesis. The University of Manchester.

Dendler, L. 2014. Sustainability Meta Labelling: an effective measure to facilitate more Sustainable Consumption and Production? Journal of Cleaner Production, 63, 74-83.

Dendler, l. and Randles, S. (Manuscript in preparation). The Role of Legitimacy Construction in Institutionalisation Processes: The Case of Social and Environmental Sustainability Labelling.

DiMaggio, P. 1988. Interest and Agency in Institutional Theory, in Zucker, Lynne (Ed.): Institutional Patterns and Organizations: Culture and Environment. Cambridge, Massachusetts: Ballinger Publishing Company, 3-21.

Dowling, J. and Pfeffer, J. 1975. Organizational Legitimacy: Social Values and Organizational Behavior. The Pacific Sociological Review 18(1), 122-136.

Erskine, C. C.; Collins, L. 1997: Eco-labelling: Success or failure? Environmentalist 17 (2), 125133.

Fan, J.; Morch, R. and Yeung, B. 2011. Capitalizing China. (NBER WORKING PAPER SERIES).

Gamer, R. E. 2008. Introduction. In R. E. Gamer (Ed.), Understanding contemporary China, 3rd ed., Boulder: Lynne Rienner Publishers, 1-10.

Garnett, T. and Wilkes, A. 2014. Appetite for change. URL: http://www.fcrn.org.uk/sites/default/files/fcrn china mapping_study final pdf 2014.pdf [checked 18.05.2015].

Geall, S. and Hilton, I. 2014. China's Environmental Governance Challenge, in Prugh, T., Renner, M. and Mastny, L (Ed.): State of the World 2014: Governing for sustainability. Washington, DC: Island Press.

Gould, D. 2015. The Organic Market Framework: Becoming Organic 3.0, in FiBL, Frick and IFOAM (Ed.): The World of Organic Agriculture. Statistics and Emerging Trends 2015. FIBL-IFOAM Report 2015. Bonn, Germany, 137-140.

Greenpeace 2006a. Greenpeace exposes two supermarket chains in HK selling vegetables containing illegal pesticide and excessive pesticide residue. http://www.greenpeace.org/eastasia/press/releases/food-agriculture/2006/20060417pesticide-vegetables/ [Checked 25.06.13].

Greenpeace 2006b. Greenpeace further exposes pesticide contamination of fruits and vegetables in Guangzhou, an alarm to Hong Kong food safety. http://www.greenpeace.org/eastasia/press/releases/food-agriculture/2006/20060612pesticide/ [Checked 25.06.13].

Greenpeace 2011a. Greenpeace testing finds illegal pesticide levels in Tesco's China produce. http://www.greenpeace.org/eastasia/press/releases/food-agriculture/2011/tescopesticides-greenpeace-testing/ [Checked 25.06.13].

Greenpeace 2011b. Tesco produce in China unsafe for three years now. http://www.greenpeace.org/eastasia/press/releases/food-agriculture/2011/tescopesticides-more-testing/ [Checked 25.06.13].

Greenpeace 2012. Banned pesticides found on supermarket produce. http://www.greenpeace.org/eastasia/press/releases/food-agriculture/2012/first-2012pesticides-report/ [Checked 25.06.13].

Greenwood, R., Suddaby, R. and Hinings, C.R 2002. Theorizing change: The role of professional associations in the transformation of institutionalised fields. Academy of Management Journal 45(1).

Gulbrandsen, L. 2006: Creating markets for eco-labelling: are consumers insignificant? International Journal of Consumer Studies 30 (5), 477-489.

Gulbrandsen, L. 2010. Transnational environmental governance: The emergence and effects of the certification of forests and fisheries. Cheltenham: Elgar.

Hale, M. 1996: Ecolabelling and cleaner production: principles, problems, education and training in relation to the adoption of environmentally sound production processes. Journal of Cleaner Production 4 (2), 85-95.

Hallmann, A. and Xu, F. 2012. Organic Certification Issues Update from East China. (Global Agricultural Inofrmation Network (GAIN) Report). 
Hatanaka, M. 2014. Standardized food governance? Reflections on the potential and limitations of chemical-free shrimp. Food Policy 45, 138-145.

Hoiman, Chan and King, Ambrose 2008. Religion, in Gamer, Robert E. (Ed.): Underchecked oning contemporary China. Boulder, Colo: Lynne Rienner Publishers, 357-395.

Horsley, J. P. 2006. Public Participation and the Democratization of Chinese Governance. In Y. Zhong and S. Hua (Eds.), Political civilization and modernization in China. The political context of China's transformation (Vol. 4, pp. 207-250). Hackensack, NJ, London: World Scientific.

$\mathrm{Hu}$, D. et al. 2004. The Emergence of Supermarkets with Chinese Characteristics: Challenges and Opportunities for China's Agricultural Development. Development Policy Review 22(5), 557-586.

Hu, D., Chen, K. and Song, H. 2008. Success Story of Linking Small Potato Farmers to Supermarkets: Some Case-Studies of Wuchuan County in Inner Mongolia Autonomous Region of China. Bangkog.

International Fund for Agricultural Development 2005. Organic Agriculture and Poverty Reduction in Asia: China and India Focus: Thematic Evaluation. Report No. 1664.

International Trade Centre (ITC) 2011. Organic Food Products in China: Market Overview: Technical Paper. Geneva.

Jacquet, J.; Pauly, D.; Ainley, D.; Holt, S.; Dayton, P.; Jackson, J. 2010: Seafood stewardship in crisis. Nature 467 (7311), 28-29.

Jia, X., Huang, J. and Xu, Z. 2012. Marketing of farmer professional cooperatives in the wave of transformed agrofood market in China. China Economic Review 23(3), 665-674.

Jordan, A. ; Wurzel, R.; Zito, A.; Brückner, L. 2006. Consumer Resposibility taking and EcoLabelling Schemes in Europe, in Micheletti, Michele (Hg.): Politics, products, and markets: Exploring political consumerism past and present. New Brunswick: Transaction Publ., 161180.

Ken Research 2013. Asia Pacific Organic Food and Beverages Industry Outlook to 2016 Expanding Distribution Channel to Augment Growth. http://www.marketresearch.com/KenResearch-v3771/Asia-Pacific-Organic-Food-Beverages-7329507/ [Checked 17.08.13].

Kirchner, C. 2015. Overview of Participatory Guarantees Systems in 2014, in FiBL, Frick and IFOAM (Ed.): The World of Organic Agriculture. Statistics and Emerging Trends 2015. FIBLIFOAM Report 2015. Bonn, 135-137.

Klein, J. 2009. Creating ethical food consumers? Promoting organic foods in urban Southwest China. Social Anthropology, 17, 74-89.

Klintman, M., Bostroeom, M., 2012. Political consumerism and the transition towards a more sustainable food regime. Looking behind and beyond the organic food shelf. In: Spaargaren, G., Oosterveer, P., Loeber, A. (Eds.), Food Practices in Transition: Changing Food

Knorringa, P.; Meijerink, G.; Schouten, G. (2011): Voluntary Governance Initiatives and the Challenges of Inclusion and Upscaling. In Helmsing et al.(Eds.): Value chains, social inclusion and economic development. Constrasting theories and realities. London: Routledge (88).

Kuehl, A. and Yonggong, L. 2014. Analytical overview of the Chinese organic sector with a focus on rural development, in Rahmann, G. and Aksoy, U. (Ed.): Proceedings of the 4th ISOFAR Scientific Conference 'Building Organic Bridges'.

Leca, B. and Naccache, P. 2006. A Critical Realist Approach to Institutional Entrepreneurship. Organization 13(5), 627-651.

Lernoud, J., Willer, H. and Kilcher, L. 2013. The world of organic agriculture: Statistics and emerging trends 2013. Frick; FiBL; IFOAM.

Li C. 2013. Food security more than just quantity. China Daily Asia Pacific 25. http://www.chinadaily.com.cn/opinion/2013-12/25/content_17194814.htm [Checked 2014-07-27].

Lin, L., Zhou, D. and Ma, C. 2010. Green food industry in China: Development, problems and policies. Renew. Agric. Food Syst 25(1), 69-80. 
Liu, Y., Langer, V., Høgh-Jensen, H., and Egelyng, H. 2010. Energy Use in Organic, Green and Conventional Pear Producing Systems-Cases from China. Journal of Sustainable Agriculture, $34(6), 630-646$.

Liu, R., Pieniak, Z. and Verbeke, W. 2013. Consumers' attitudes and behaviour towards safe food in China: A review. Food Control 33(1), 93-104.

Marchesini, S. 2009. Perceptual maps analysis for organic food consumers in China: a study on Shanghai consumers. DOTTORATO DI RICERCA IN ECONOMIA E POLITICA AGRARIA E ALIMENTARE. Università di Bologna.

Meidinger, E. 2008. Multi-Interest Self-Governance through Global Product Certification Programmes, in Dilling, O., Herberg, M. and Winter, G. (Ed.): Responsible business: Selfgovernance and law in transnational economic transactions. Oxford, 258-291.

Meng, F. et al. 2015. Organic Industry Development Report of China (Excerpt). Organic Agricultural Technology Centre.

Mol, A. 2014. Governing China's food quality through transparency: A review. Food Control 43(0), 49-56.

Tan, M. 2012. Want to eat organic in China? Here's how! http://www.greenpeace.org/eastasia/news/blog/want-to-eat-organic-inchina/blog/40399/ [Checked 25.06.13].

National Standard of the People's Republic of China. Organic Products Part 3: Labeling and Marketing, General Administration of Quality Supervision, Inspection and Quarantine of the People's Republic of China; Standardization Administration of the People's Republic of China 12.05.2011.

Oberheitman, A. 2009. Envronmental policy reform inChina, in Heberer, T. and Schubert, G.(Ed.): Regime legitimacy in contemporary China: Institutional change and stability. London, New York: Routledge, 268-296.

Oelofse, M. et al. 2010. Certified organic agriculture in China and Brazil: Market accessibility and outcomes following adoption. Ecological Economics 69(9), 1785-1793.

Oelofse, M. et al. 2011. Organic farm conventionalisation and farmer practices in China, Brazil and Egypt. Agron. Sustain. Dev., 31, 689-698.

Offermann, F., Nieberg, H. and Zander, K. 2009. Dependency of organic farms on direct payments in selected EU member states: Today and tomorrow. Development of organic farming policy in Europe 34(3), 273-279.

OFDC n.d. URL: www.ofdc.org.cn [Checked 10.03.14].

OFDC-MEP n.d. Organic Food Development Center of MEP, China (OFDC-MEP), Organic Food Development and Certification Center of China (OFDC): Promotional Flyer [Checked 2014-07$11]$.

OFRC 2006-2014. Nanjing Global Organic Food Research and Consulting Center. http://www.ofrcc.com/ [Checked 2014-07-10].

Organic Trade Association N.Y. China. Brattleboro, USA. URL: www.ota.com.

Ortega, D. et al. 2011. Modeling heterogeneity in consumer preferences for select food safety attributes in China. Food Policy 36(2), 318-324.

Paull, J. 2008. The Greening of China's Food - Green Food, Organic Food, and Eco-labelling, in Liege University (Ed.): Sustainable Consumption and Alternative Agri-Food Systems Conference, 1-14.

Qiao, Yuhui 2014. Consumption of Organic Food in China. Renmin University, China.

Qiao Yuhui 2010. Organic Farming Research in China: Organic Research Centre Alliance. http://www.orca-research.org/orca-china.html [Checked 14.02.14].

Redding, G. and Witt, M. 2006. The "Tray of Loose Sand:" A Thick Description of the State-Owned Enterprise Sector of China Seen as a Business System. Asian Business and Management 5(1).

Reisch, L., Eberle, U., Lorek, S., 2013. Sustainable food consumption: an overview of contemporary issues and policies. Sustainability: Science, Practise and Policy 9 (2), 1-19.

Sanders, R. 2006a. Organic Agriculture in China: do property rights matter? Journal of Contemporary China 15(46), 113-132. 
Sanders, R. 2006b. A Market Road to Sustainable Agriculture? Ecological Agriculture, Green Food and Organic Agriculture in China. Development and Change, 37(1), 201-226.

Scott, G. and Suarez, V. 2012. Limits to Growth or Growth to the Limits? Trends and Projections for Potatoes in China and Their Implications for Industry. Potato Research 55, 135-156.

Scott, S. et al. 2014. Contradictions in state- and civil society-driven developments in China's ecological agriculture sector. Food Policy 45(0), 158-166.

Selden, M. and Perry, E. 2010. Introduction: reform, conflict and resistance in contemporary China, in Perry, E. and Selden, M. (Ed.): Chinese society: Change, conflict and resistance. Abingdon, Oxford, New York: Routledge, 1-30.

Sheng, J., et al. 2009. Market trends and accreditation systems for organic food in China. Trends in Food Science and Technology 20(9), 396-401.

Shi, W., Markóczy, L., and Stan, C. V. 2014. The Continuing Importance of Political Ties in China. The Academy of Management Perspectives, 28(1), 57-75.

Si, Z., Schumilas, T. and Scott, S. 2014. Characterizing alternative food networks in China. Agriculture and Human Values, 1-15.

Sirieix, L., Kledal, P., and Sulitang, T. 2011. Organic food consumers' trade-offs between local or imported, conventional or organic products: a qualitative study in Shanghai. International Journal of Consumer Studies, 35, 670-678.

Steering Committee of the State-of-Knowledge Assessment of Standards and Certification 2012. Toward sustainability: The roles and limitations of certification. Washington, DC.

Steinrücken, T.; Jaenichen, S. 2007: The fair trade idea: Towards an economics of social labels. Journal of Consumer Policy 30 (3), 201-21

Stolze, M. and Lampkin, N. 2009. Policy for organic farming: Rationale and concepts. Development of organic farming policy in Europe 34(3), 237-244.

Suchman, M. 1995. Managing Legitimacy: Strategic and Institutional Approaches. The Academy of Management Review 20(3), 571-610.

Sun, Y. and Zhao, D. 2007. Multifaceted State and Fragmented Society: Dynamics of Environmental Movement in China, in Yang, Dali L. (Ed.): Discontented miracle: Growth, conflict, and institutional adaptations in China. New Jersey: World Scientific, 111-160.

Tang, L. 2009. The Chinese Consumer Market: Opportunities and Risks. Oxford, Cambridge, New Delhi: Chandos Publishing.

Taylor, D. 2008. Recovering the Good Earth: China's Growing Organic Market. Environ Health Perspect. 116(8), A346-A349.

Thiers, P. 2002. From grassroots movement to state-coordinated market strategy: The transformation of organic agriculture in China. Environment and Planning C: Government and Policy 20(3), 357-373.

Thiers, P. 2005. Using global organic markets to pay for ecologically based agricultural development in China. Agriculture and Human Values, 22, 3-15.

Thøgersen, J. and Zhou, Y. 2012. Chinese consumers' adoption of a 'green' innovation - The case of organic food. Journal of Marketing Management 28(3-4), 313-333.

Thøgersen, J., de Barcellos, M., Perin, M. G., and Zhou, Y. (2015a). Consumer buying motives and attitudes towards organic food in two emerging markets. International Marketing Review, 32(3/4), 389-413.

Thøgersen, J., Zhou, Y., and Huang, G. (2015b). How stable is the value basis for organic food consumption in China? Journal of Cleaner Production, in press.

Tost, L. 2011. An integrative model of legitimacy judgments. Academy of Management Review 36(4), 686-710.

Veeck, A. and Burns, A. 2005. Changing tastes: the adoption of new food choices in post-reform China. Journal of Business Research 58(5), 644-652.

Veeck, A., Hongyan, Y. and Burns, A. 2010. Consumer Risks and New Food Systems in Urban China. Journal of Macromarketing 30(3), 222-237. 
Vitters $\emptyset$, G. and Tangeland, T. 2015. The role of consumers in transitions towards sustainable food consumption. The case of organic food in Norway. Journal of Cleaner Production 92(0), 91-99.

Waddell, S. and Khagram, S. 2007. Multi-stakeholder global networks: emerging systems for the global common good, in Glasbergen, P., Biermann, F. and Mol, A. (Hg.): Partnerships, governance and sustainable development: Reflections on theory and practice. Cheltenham, UK, Northampton, MA: Edward Elgar, 261-287.

Wai, O. 2015. Organic Asia 2014, in FiBL, Frick and IFOAM (Ed.): The World of Organic Agriculture. Statistics and Emerging Trends 2015. FIBL-IFOAM Report 2015. Bonn, Germany.

Walder, A. 2011. From Control to Ownership: China's Managerial Revolution. Management and Organization Review, 7(1), 19-38.

Walley, K. et al. 2014. The influence of country of origin on Chinese food consumers. Transnational Marketing 2(2), 78-98.

Wang, G. 2011. Wal-Mart stores closed and fined over falsely labeled pork in SW China. http://news.xinhuanet.com/english2010/china/2011-10/10/c_131181622.htm [Checked 11.305.2015].

Wang, M. 2014a. The Policy and Regulations of Certification and Accreditation of Chinese organic Product. Shanghai.

Wang, Z., Mao, Y., and Gale, F. 2008. Chinese consumer demand for food safety attributes in milk products. Food Policy, 33(1), 27-36.

Wang, P., Liu, Q. and Qi, Y. 2014. Factors influencing sustainable consumption behaviors: a survey of the rural residents in China. Special Volume: Sustainable Production, Consumption and Livelihoods: Global and Regional Research Perspectives 63(0), 152-165.

Wang, Y. 2014b. Polluted farmland leads to Chinese food security fears: china dialogue. https://www.chinadialogue.net/article/show/single/en/6636-Polluted-farmland-leads-toChinese-food-security-fears [checked 17.05.2015].

Wang, Z. 2005. Political Trust in China: Forms and Causes, in White, Lynn T. (Ed.): Legitimacy: Ambiguities of political success or failure in East and Southeast Asia. New Jersey, Hong Kong: World Scientific. (1), 113-140.

Weber, M. (1922). Wirtschaft und Gesellschaft: Grundriß der verstehenden Soziologie. http://www.textlog.de/7290.html

Wei, Z. 2012. Organic certification officials regularly accept 'gifts' from food companies in China. https://www.chinadialogue.net/article/show/single/en/5211-Organic-certificationofficials-regularly-accept-gifts-from-food-companies-in-China [checked 17.05.2015].

Whitehead, R. 2015. Chinese authorities plan 22-month crackdown on food safety. http://www.foodnavigator-asia.com/Policy/Chinese-authorities-plan-22-monthcrackdown-on-food-safety [Checked 2015-03-06].

Wiel, S. and McMahon, J. 2005. Energy efficiency labels and standards: A guidebook for aplliances, equipment, and lighting. 2. Ed. Washington, DC.

Wilkinson, R. 2007. Fair Trade: Dynamic and Dilemmas of a Market oriented Global Social Movement. Journal of Consumer Policy 30, 219-239.

Willer, H. and Lernoud, J. 2015. The World of Organic Agriculture. Statistics and Emerging Trends 2015. FIBL-IFOAM Report 2015. Bonn, Germany.

$\mathrm{Wu}, \mathrm{L} ., \mathrm{Xu}, \mathrm{L}$. and Gao, J. 2011. The acceptability of certified traceable food among Chinese consumers. British Food Journal 113(4), 519-534.

Wu, L., Yin, S., Xu, Y., and Zhu, D. 2014. Effectiveness of China's Organic Food Certification Policy: Consumer Preferences for Infant Milk Formula with Different Organic Certification Labels. Canadian Journal of Agricultural Economics, 62, 545-568.

Xi, Y. 2010. Organic food and organic farming for large scale supply chains in China. http://www.ofrcc.com/en/HTML/812.html [Checked 2014-07-17].

Xiao, P. (16.06.2015). China's Social Co-regulation: A Principle as Adopted in the New Food Safety Law: Selerant Corporation. http://compliancecloud.selerant.com/latestnews/chinaregulation-new-food-safety-law.aspx [checked 09.10.2015]. 
Xie, B., Tingyou, L. and Yi, Q. 2011. Organic certification and the market: Organic exports from and imports to China. Br. Food J 113(10), 1200-1216.

Xie, B., Wang, L., Yang, H., Wang, Y., and Zhang, M. 2015. Consumer perceptions and attitudes of organic food products in Eastern China. British Food Journal,

Xu, P., Zeng, Y., Fong, Q., Lone, T., and Liu, Y. (2012). Chinese consumers' willingness to pay for green- and eco-labeled seafood. Food Control, 28(1), 74-82.

Yang, Y. 2011/2012. Strategy for the launch of Whole Foods Market in China. The University of Liverpool.

Yang, W. 2011. Pesticides bring a silent spring. China Daily Asia Pacific 19. October. http://www.chinadailyapac.com/article/pesticides-bring-silent-spring.

Yi, Q., Hui, X., Bu-zhuo, P., and Xiliu, J. 2001. Development Strategy for Organic Food Industry in China. A Journal of the Human Environment, 30(7), 450-451.

Yin, S. et al. 2010. Consumers' purchase intention of organic food in China. J. Sci. Food Agric 90(8), 1361-1367.

Yip, L., and Janssen, M. 2015. How do consumers perceive organic food from different geographic origins? Evidence from Hong Kong and Shanghai. Journal of Agriculture and Rural Development in the Tropics and Subtropics, 116(1), 71-84.

Zhan, L., Ju, M. and Liu, J. 2011. Improvement of China Energy Label System to Promote Sustainable Energy Consumption. 2010 International Conference on Energy, Environment and Development - ICEED2010 5(0), 2308-2315.

Zhang, C. et al. 2010. How do consumers determine the safety of milk in Beijing, China? Supplement: CES 2009 Supplement: CES 2009 21, Supplement 1(0), S45.

Zhang, C.; Bai, J. and Wahl, Thomas I. 2012. Consumers' willingness to pay for traceable pork, milk, and cooking oil in Nanjing, China. Food Control 27(1), 21-28.

Zhang, X., et al. 2008. Consumption and corpulence in China. A consumer segmentation study based on the food perspective. Food Policy 33(1), 37-47.

Zhang, J. 2011. Organic food worries. China Central Television. http://english.cntv.cn/20111103/112225.shtml [Checked 2014-07-27].

Zhang, L.-X., Hu, Q.-H., and Wang, C.-B. 2013. Emergy evaluation of environmental sustainability of poultry farming that produces products with organic claims on the outskirts of mega-cities in China. Ecological Engineering, 54, 128-135.

Zhang, L.; Feike, T.; Holst, J.; Hoffmann, C., and Doluschitz, R. 2015. Comparison of energy consumption and economic performance of organic and conventional soybean production - $\mathrm{A}$ case study from Jilin Province, China. Journal of Integrative Agriculture, 14(8), 1561-1572.

Zhou, Y., Thøgersen, J., Ruan, Y., and Huang, G. 2013. The moderating role of human values in planned behavior: the case of Chinese consumers' intention to buy organic food. Journal of Consumer Marketing, 30(4), 335-344. 


\section{Appendix 1}

\begin{tabular}{|c|c|c|c|c|c|c|}
\hline No & Actor Group & Date & Location & Recording & Language & Position \\
\hline 1 & Academia & 27.2 .14 & Beijing & Yes & English & Postgraduate Student \\
\hline 2 & Academia & 31.3.14 & Hohhot & Yes & Mandarin & Professor \\
\hline 3 & Academia & 19.1.14 & Harbin & Yes & English & Postdoctoral Researcher \\
\hline 4 & Academia & 27.2 .14 & Beijing & Yes & English & Professor \\
\hline 5 & Certification Organisation & 23.5.14 & $\begin{array}{l}\text { Biofach } \\
\text { Shanghai }\end{array}$ & No & English & Project Assistant \\
\hline 6 & Certification Organisation & 25.11 .13 & $\begin{array}{l}\text { Beijing } \\
\text { Organic Fair }\end{array}$ & Yes & Mandarin & Office Director \\
\hline 7 & Certification Organisation & 28.11 .14 & Beijing & Yes & English & Manager/Senior Inspector \\
\hline 8 & Certification Organisation & 28.2.14 & Beijing & Yes & English & Project engineer \\
\hline 9 & Certification Organisation & 17.1.14 & Beijing & $\begin{array}{l}\text { Email } \\
\text { Response }\end{array}$ & Mandarin & No information \\
\hline 10 & Certification Organisation & 22.11 .13 & $\begin{array}{l}\text { Beijing } \\
\text { Organic Fair }\end{array}$ & Yes & Mandarin/English & Regional Manager \\
\hline 11 & Certification Organisation & 28.2.14 & Beijing & Yes & Mandarin/English & Deputy General Manager \\
\hline 12 & Certification Organisation & 28.2.14 & Beijing & Yes & Mandarin/English & General Manager \\
\hline 13 & Certification Organisation & 22.1 .14 & Harbin & No & Mandarin & Certifier \\
\hline 14 & Certification Organisation & 12.1.14 & Hangzhou & Yes & English & Technical Manager \\
\hline 15 & $\begin{array}{l}\text { Labelling/Governmental } \\
\text { Organisation }\end{array}$ & 17.1.14 & Beijing & Yes & Mandarin & Director \\
\hline 16 & $\begin{array}{l}\text { Labelling/Governmental } \\
\text { Organisation }\end{array}$ & 27.2 .14 & Beijing & Yes & Mandarin & $\begin{array}{l}\text { Director of personnel certification department; } \\
\text { Secretary general }\end{array}$ \\
\hline 17 & $\begin{array}{l}\text { Labelling/Governmental } \\
\text { Organisation }\end{array}$ & 17.1.13 & Beijing & No & Mandarin & Director \\
\hline 18 & Governmental Organisation & 24.1 .14 & Harbin & No & Mandarin & Government Official \\
\hline 19 & $\begin{array}{l}\text { Labelling/Governmental } \\
\text { Organisation }\end{array}$ & 11.3.14 & Nanjing & Yes & Mandarin & Research Fellow \\
\hline 20 & $\begin{array}{l}\text { Labelling/Governmental } \\
\text { Organisation }\end{array}$ & 11.3.14 & Nanjing & Yes & Mandarin & Deputy Director \\
\hline 21 & NGO & 11.3.14 & $\begin{array}{l}\text { Beijing } \\
\text { Organic Fair }\end{array}$ & Yes & Mandarin & Project manager \\
\hline
\end{tabular}




\begin{tabular}{|c|c|c|c|c|c|c|}
\hline 22 & NGO & 27.2 .14 & Beijing & No & English & Climate and energy campaigner \\
\hline 23 & NGO & 26.12 .14 & Shanghai & Yes & Mandarin & Founder \\
\hline 24 & NGO & 21.10 .13 & $\begin{array}{l}\text { Shanghai } \\
\text { Organic Fair }\end{array}$ & Yes & Mandarin & Editor \\
\hline 25 & Multinational Manufacturer & 6.11 .13 & Telephone & yes & English & Senior Food Safety Manager \\
\hline 26 & Multinational Manufacturer & 22.5 .14 & $\begin{array}{l}\text { Shanghai } \\
\text { Biofach }\end{array}$ & Yes & English & Global Sales Manager \\
\hline 27 & $\begin{array}{l}\text { Multinational Manufacturer } \\
\text { and Producer }\end{array}$ & 24.1 .13 & Harbin & No & English & Founder \\
\hline 28 & Multinational Manufacturer & 3.9 .14 & Manchester & Yes & German & Export Director \\
\hline 29 & Manufacturer and Producer & 11.3.14 & Changzhou & No & Mandarin & Manager \\
\hline 30 & Manufacturer and Producer & 28.3 .14 & Hohhot & No & Mandarin & Quality Manager in charge of certification \\
\hline 31 & Manufacturer and Producer & 23.3.14 & Hohhot & Yes & Mandarin & Vice President \\
\hline 32 & Manufacturer and Producer & 27.1.14 & Harbin & No & Mandarin & Manager in charge of organic \\
\hline 33 & Manufacturer and Producer & 27.3 .14 & Telephone & Yes & Mandarin & Senior Manager \\
\hline 34 & Manufacturer and Producer & 27.3 .14 & Hohhot & No & Mandarin & General Manager Quality Control \\
\hline 35 & Manufacturer and Producer & 26.2 .14 & Shandong & Yes & Mandarin & Vice President \\
\hline 36 & Manufacturer and Producer & 26.2 .14 & Shandong & Yes & Mandarin & Processing Manager \\
\hline 37 & Manufacturer and Producer & 26.2 .14 & Shandong & Yes & Mandarin & Certification Manager \\
\hline 38 & Manufacturer and Producer & 30.12 .13 & Shanghai & Yes & Mandarin & Sales Chief Inspector \\
\hline 39 & Manufacturer and Producer & 23.5.14 & $\begin{array}{l}\text { Biofach } \\
\text { Shanghai }\end{array}$ & Yes & Mandarin & Executive Consultant \\
\hline 40 & Manufacturer and Producer & 25.5 .13 & $\begin{array}{l}\text { Biofach } \\
\text { Shanghai }\end{array}$ & No & Mandarin & Sales Manager \\
\hline 41 & Manufacturer and Producer & 25.11 .13 & $\begin{array}{l}\text { Beijing } \\
\text { Organic Fair }\end{array}$ & Yes & Mandarin & Sales Advisor \\
\hline 42 & Manufacturer and Producer & 25.5 .13 & $\begin{array}{l}\text { Biofach } \\
\text { Shanghai }\end{array}$ & No & Mandarin & Sales Manager \\
\hline 43 & Manufacturer and Producer & 23.5 .14 & $\begin{array}{l}\text { Biofach } \\
\text { Shanghai }\end{array}$ & Yes & Mandarin & Marketing Manager \\
\hline 44 & Primary Producer & 23.5.14 & $\begin{array}{l}\text { Biofach } \\
\text { Shanghai }\end{array}$ & Yes & Mandarin & Procurement Manager \\
\hline 45 & Primary Producer & 25.11 .13 & $\begin{array}{l}\text { Beijing } \\
\text { Organic Fair }\end{array}$ & Yes & Mandarin & General Manager \\
\hline 46 & Primary Producer & 24.1 .13 & Harbin & No & Mandarin & Cooperative Manager \\
\hline
\end{tabular}




\begin{tabular}{|c|c|c|c|c|c|c|}
\hline 47 & Primary Producer & 27.1 .14 & Harbin & No & Mandarin & Cooperative Manager \\
\hline 48 & Primary Producer & 21.10 .13 & $\begin{array}{l}\text { Shanghai } \\
\text { Organic Fair }\end{array}$ & No & Mandarin & Cooperative Manager \\
\hline 49 & Primary Producer & 28.3 .14 & Hohhot & No & Mandarin & Cooperative Manager \\
\hline 50 & Primary Producer & 25.5 .13 & $\begin{array}{l}\text { Biofach } \\
\text { Shanghai }\end{array}$ & No & Mandarin & Trade Fair Representative \\
\hline 51 & Primary Producer & 22.5 .14 & $\begin{array}{l}\text { Biofach } \\
\text { Shanghai }\end{array}$ & Yes & Mandarin & Vice general manager for production \\
\hline 52 & Primary Producer & 25.5 .13 & $\begin{array}{l}\text { Biofach } \\
\text { Shanghai }\end{array}$ & No & Mandarin & Trade Fair Representative \\
\hline 53 & Primary Producer & 21.11 .13 & $\begin{array}{l}\text { Beijing } \\
\text { Organic Fair }\end{array}$ & No & Mandarin & Trade Fair Representative \\
\hline 54 & Primary Producer & 25.5 .13 & $\begin{array}{l}\text { Biofach } \\
\text { Shanghai }\end{array}$ & No & Mandarin & Sales Manager \\
\hline 55 & Primary Producer & 25.5 .13 & $\begin{array}{l}\text { Biofach } \\
\text { Shanghai }\end{array}$ & No & Mandarin & Product Manager \\
\hline 56 & Primary Producer & 22.5 .14 & $\begin{array}{l}\text { Biofach } \\
\text { Shanghai }\end{array}$ & Yes & Mandarin & Marketing manager \\
\hline 57 & Primary Producer & 23.5.14 & $\begin{array}{l}\text { Biofach } \\
\text { Shanghai }\end{array}$ & No & Mandarin & Trade Fair Representative \\
\hline 58 & Primary Producer & 22.11 .13 & $\begin{array}{l}\text { Beijing } \\
\text { Organic Fair }\end{array}$ & No & Mandarin & Sales Manager \\
\hline 59 & Primary Producer & 25.11 .14 & $\begin{array}{l}\text { Beijing } \\
\text { Organic Fair }\end{array}$ & Yes & Mandarin & Trade Fair Representative \\
\hline 60 & Primary Producer & 25.5 .13 & $\begin{array}{l}\text { Biofach } \\
\text { Shanghai }\end{array}$ & No & Mandarin & Trade Fair Representative \\
\hline 61 & Organic Retailer & 19.3.14 & Shanghai & Yes & Mandarin & President China \\
\hline 62 & Organic Retailer & 23.5 .14 & $\begin{array}{l}\text { Biofach } \\
\text { Shanghai }\end{array}$ & No & English/German & Trade Fair Representative \\
\hline 63 & Retailer & 22.3.14 & Fudan & No & English & President China \\
\hline 64 & Retailer & 6.3 .14 & Shanghai & Yes & English & Head of quality management \\
\hline 65 & Retailer & 6.3 .14 & Shanghai & Yes & English & Quality Manager \\
\hline 66 & Retailer & 23.11 .13 & Beijing & Yes & Mandarin/English & Director of Sustainable Promotion Department \\
\hline 67 & Retailer & 8.11 .13 & Shanghai & Yes & Mandarin & Department Manager \\
\hline 68 & Retailer & 20.5 .14 & Shanghai & Yes & English & Senior Sustainability Manager \\
\hline 69 & Distributor & 23.5 .14 & Biofach & Yes & English & Brand Supervisor and General Manager \\
\hline
\end{tabular}




\begin{tabular}{|c|c|c|c|c|c|c|}
\hline & & & Shanghai & & & \\
\hline 70 & Distributor & 24.5 .14 & $\begin{array}{l}\text { Biofach } \\
\text { Shanghai }\end{array}$ & No & English & Trade Fair Representative \\
\hline 71 & Distributor & 29.3.14 & Hohhot & Yes & Mandarin/English & Trade Fair Representative \\
\hline 72 & Distributor & 24.5.14 & $\begin{array}{l}\text { Biofach } \\
\text { Shanghai }\end{array}$ & Yes & English & Trade Fair Representative \\
\hline 73 & Distributor & 25.5 .13 & $\begin{array}{l}\text { Biofach } \\
\text { Shanghai }\end{array}$ & No & Mandarin & Trade Fair Representative \\
\hline 74 & $\begin{array}{ll}\text { International } & \text { Umbrella } \\
\text { Organisation } & \\
\end{array}$ & 5.6 .13 & Shanghai & No & English & Asia Representative \\
\hline \multicolumn{7}{|c|}{ Informal Conversations } \\
\hline 75 & Primary producer & 7.6.13 & Beijing & N.a. & English & No information \\
\hline 76 & Distributor & 21.10 .13 & $\begin{array}{l}\text { Shanghai } \\
\text { Organic Fair }\end{array}$ & N.a. & Mandarin & General Manager \\
\hline 77 & Primary producer & 25.11 .14 & $\begin{array}{l}\text { Shanghai } \\
\text { Farmers } \\
\text { Market }\end{array}$ & N.a. & English & Sales Director \\
\hline 78 & Primary producer & 16.6.13 & Shanghai & N.a. & English & Director of Agriculture \\
\hline 79 & Primary producer & 27.2 .14 & Shandong & N.a. & Mandarin & Manager Large Scale Farm \\
\hline 80 & Manufacturer & 22.5 .14 & $\begin{array}{l}\text { Biofach } \\
\text { Shanghai }\end{array}$ & N.a. & English & Trade Fair Representative \\
\hline 81 & Trader & 22.5.14 & $\begin{array}{l}\text { Biofach } \\
\text { Shanghai }\end{array}$ & N.a. & Mandarin & Trade Fair Representative \\
\hline
\end{tabular}




\section{Appendix 2}

\begin{tabular}{|l|l|}
\hline AFN & Alternative Food Networks \\
\hline CNCA & Accreditation Administration of the People's Republic of China \\
\hline CSA & Community Supported Agriculture \\
\hline COFCC & China Organic Food Certification Centre \\
\hline FIBL & Research Institute of Organic Agriculture \\
\hline IFAD & International Fund for Agricultural Development \\
\hline IFOAM & International Federation for Organic Agricultural Movement \\
\hline ITC & International Trade Centre \\
\hline MEP & Ministry of Environmental Protection \\
\hline OFDC & Organic Food Development Centre \\
\hline OFRC & Organic Food Research and Consulting Centre \\
\hline PGS & Participatory Guarantee Systems \\
\hline SEPA & State Environment Protection Agency \\
\hline USDA & United States Department of Agriculture \\
\hline
\end{tabular}

